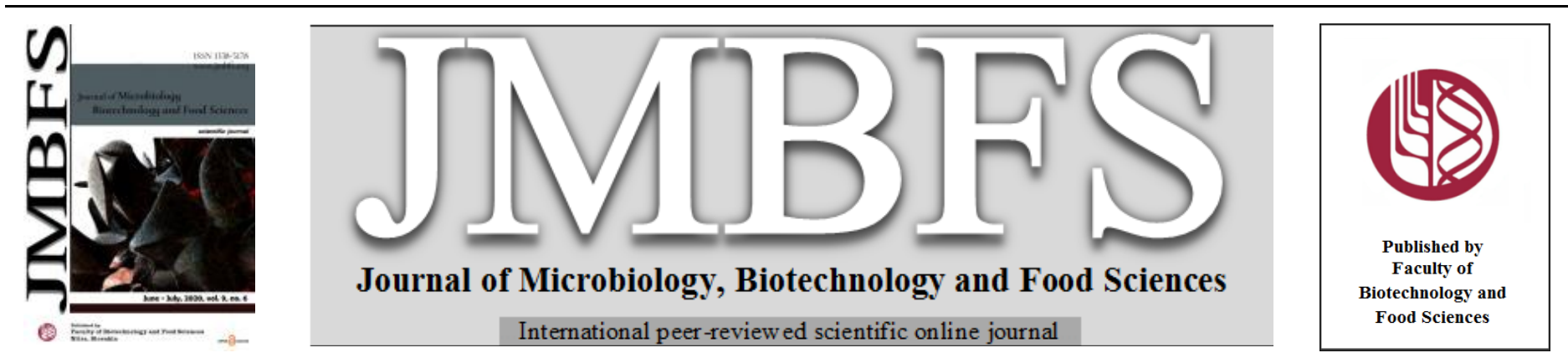

\title{
DIFFERENCES IN FYTOCHEMICALS CONTENT IN COLOURED CULTIVARS OF COMMON BEAN (PHASEOLUS VULGARIS L.)
}

\section{Ivana Tirdil'ová $*^{l}$, Alena Vollmannová ${ }^{l}$, Ivona Jančo ${ }^{l}$, Marek $\check{S}_{\text {nirc }}{ }^{l}$}

Address(es): Ing. Ivana Tirdilová,

${ }^{1}$ Slovak University of Agriculture in Nitra, Faculty of Biotechnology and Food Sciences, Department of Chemistry, Tr. A. Hlinku 2, 94976 Nitra, Slovakia.

*Corresponding author: ivana.ika.tirdilova@gmail.com

doi: $10.15414 /$ jmbfs.2020.9.6.1187-1190

\section{ARTICLE INFO}

Received 5. 9. 2019

Revised 5. 2. 2020

Accepted 14. 2. 2020

Published 1. 6. 2020

Regular article oPEN $\partial_{\text {ACCESS }}$

\begin{abstract}
Nowadays, legume production is increasing as the world population but its consumption is declining due to dietary habit changes. Industry is finding new uses of legumes and creating new foods with a positive effect on health and well-being of humans. Key components in legume (like protein, soluble and insoluble fibre, resistant starch, and bioactive polyphenols) make beans suitable for a wide range of food product applications. The main phenolic compounds present in legume flours are flavonoids. The study is focused on determination of bioactive compounds content in seeds of four varieties of common bean. The samples of plant material were collected from the area of Pieštany (Slovakia). The samples of common bean seeds were homogenized and a methanolic extract was prepared. These extracts were used for analyses. The total content of polyphenols was determined spectrophotometrically and the content of individual phenolic by using the RP-HPLC/DAD method. The content of risky metals in samples was determined using the AAS method. TPC in studied varieties of common bean were determined in the range from $2156.87 \mathrm{mg} . \mathrm{kg}^{-1}$ (NEGRA) to $1362.70 \mathrm{mg}$. $\mathrm{kg}^{-1}$ (ZENIT). Highest concentration of phenolic acids was determined in ellagic acid, where the average value was $0.21845 \mathrm{mg} \cdot \mathrm{kg}^{-1} \mathrm{DM}$ (dry matter) and the lowest in trans- caffeic acid, with the average value $0.02380 \mathrm{mg} \cdot \mathrm{kg}^{-1} \mathrm{DM}$. Highest concentration of flavonoids was determined in vitexin, where the average value was $0.02480 \mathrm{mg} \cdot \mathrm{kg}^{-1} \mathrm{DM}$ and the lowest in kaempferol, with the average value 0.00545 mg.kg ${ }^{-1}$ DM. Highest macro elements amount was determined in white beans. For potassium it was $12277 \mathrm{mg} . \mathrm{kg}^{-1}$ (ZENIT) and the lowest was in manganese, and it was $10.70 \mathrm{mg} \cdot \mathrm{kg}^{-1}$ (RUBIN) in red beans. From the analyzed varieties we have found that they are important source of polyphenol substances with a demonstrable bioactive effect.
\end{abstract}

\section{INTRODUCTION}

Common bean (Phaseolus vulgaris L.) is one of the most widely produced legume specie in the world, for its edible beans, used both as dry seed and as unripe fruits. The leaf is occasionally used as a vegetable, and the straw is used for fodder (Li et al., 2016). Common bean (P. vulgaris) is one of the most important legume crops, providing as much as $15 \%$ of total daily calories and $36 \%$ of total daily protein in parts of Africa and the America (Nemli et al., 2015). In Canada, both white and coloured beans exist. The different market classes of coloured beans include pinto, brown, cranberry, azuki, dark and light red kidney, small red, pink, and black (Pitura et al., 2019). Common bean is the most important grain legume for human direct consumption (Herrera et al. 2019) and is considered as a key source of minerals (4-6\% ash) (Pitura et al., 2019) like iron and zinc, proteins (20-27\%), and complex of carbohydrates (up to $60 \%$ ), dietary fiber (up to $28 \%$ ), vitamins, as well as bioactive compounds (such as polyphenols, phytosterols and saponins) (Aguilera et al., 2011; Herrera $\boldsymbol{e t}$ al. 2019

Research suggests that the beans with darker coloured seed coats have higher total flavonoid contents, when compared to those with lighter coloured seed coats. More than 200 flavonol aglycones have been identified in plants. Among these, quercetin $\left(3,5,7,3^{\prime}, 4^{\prime}\right.$-pentahydroxyflavone), kaempferol (3,5,7,4'tetrahydroxyflavone), myricetin $\left(3,5,7,3^{\prime}, 4^{\prime}, 5^{\prime}\right.$-hexahydroxyflavone), and isorhamnetin (3,5,7,4'-tetrahydroxy-3'-methoxy flavone) are the most abundant in food. It is generally believed that bean seed coat colour is due to the presence of flavonols, as well as the other phenolic compounds, including anthocyanins and tannins. Flavonols in beans are mainly concentrated in the seed coat. Beans with white seed coats do not contain flavonol compounds (Pitura et al., 2019).
Phenolic compounds, commonly found in edible and non-edible plants, have been reported to possess multiple biological effects, including antioxidant activity. In the human diet, polyphenols make the most important contribution to antioxidant activity (Alshikh et al.,2015). As antioxidants, phenolic compounds are able to decrease oxygen concentration, intercept singlet oxygen (Alshikh et al.,2015), prevents or remove oxidative damage to a target molecule. Antioxidants are an inhibitor of the oxidation process, even at relatively small concentration and thus have diverse physiological role in the body. A variety of free radical scavenging antioxidants is found in dietary sources like fruits, vegetables and tea (Yadav $\boldsymbol{e}$ al., 2016). Numerous of publications have reported the health benefits of phenolic compounds in disease risk reduction, for example as the protection against cancer (Mirali et al., 2014), including those of breast, colon, prostate, and stomach as well as cardiovascular disease and various inflammatory disorders (Mirali et al., 2014).

Common bean also contain components such as organic acids and tocopherols, which are considered as bioactive components. Their effects have health benefits related to the antihypertensive, antibacterial and antioxidant potential, and the protective effects in oxidative stress-induction, such as the carcinogenesis inhibitory effect (Arribas et al., 2019). This plant has been used as carminative, diuretic,

emollient

and also in the treatment of diabetes, diarrhea, dysentery, and kidney problems (Kuete, 2014).

\section{MATERIAL AND METHODS}

Studied plant material was obtained from the Plant Research Canter in Pieštany (Slovakia). We analysed four varieties (NEGRA- black beans, RUBIN- red beans, INKA- colour beans, ZENIT- white beans) of common beans (Phaseolus $\begin{array}{lllll}\text { vulgaris } & \mathrm{L} \text {.) } & \text { The } & \text { total }\end{array}$ 
of polyphenol substances, individual phenols, as well as the content of macro and microelements were determined in common beans seeds.

\section{Plant material}

Seeds of four common beans cultivars (NEGRA, RUBIN, INKA, ZENIT) were manually separated, then dried at $105^{\circ} \mathrm{C}$ to a constant weight and finally pulverized (Grindomix 200 GD, Retsch, Germany).

\section{Determination of risk elements content}

Plant samples ( $1 \mathrm{~g})$ were mineralized in a closed microwave digestion system (Mars X-Press 5, CEM Corp., USA) in a mixture of $5 \mathrm{~cm}^{3} \mathrm{HNO}_{3}$ (Suprapur, Merck, Germany) and $5 \mathrm{~cm}^{3}$ deionized water $(0.054$ $\mu \mathrm{S} / \mathrm{cm}$, Simplicity 185, Millipore, UK). Digestive conditions for the applied microwave system comprised heating to $160{ }^{\circ} \mathrm{C}$ for 15 minutes and kept it constant for 10 minutes. A blank sample was treated in the same way. The digested substances were subsequently filtered through a quantitative filter paper Filtrak 390 (Munktell, Germany) and filled up with deionized water to a volume of $50 \mathrm{~cm}^{3}$. Contents of risk elements $(\mathrm{Zn}, \mathrm{Cu}$ $\mathrm{Ni}, \mathrm{Cr}, \mathrm{Pb}$ and $\mathrm{Cd}$ ) were determined by F-AAS and GF-AAS method (Varian AA Spectr DUO 240FS/240Z/UltrAA, Varian, Australia) and expressed as mg/100 DM

(dry matter). The graphite furnace technique was used for the determination of $\mathrm{Pb}$ and $\mathrm{Cd}$, whereas the flame AAS method was used for the determination of $\mathrm{Zn}, \mathrm{Cu}, \mathrm{Ni}$ and $\mathrm{Cr}$. Gained results were evaluated according to FC SR (Food Codex of the Slovak Republic valid in Slovakia) as well as according Commission Regulation (EC) 1881/2006

\section{Determination of phenolic acids and flavonoids Chemicals}

Standard chemicals (trans- caffeic acid, syringic acid, ellagic acid, trans pcoumaric acid, trans-sinapic acid, ferulic acid, vitexin, resveratrol, daidzein, kaempferol), methanol (HPLC grade), acetonitrile (gradient HPLC grade) and phosphoric acid (ACS grade) were purchased from Sigma-Aldrich (Sigma Aldrich Chemie GmbH, Steiheim, Germany) Deionized water $\left(0.054 \mu \mathrm{S} . \mathrm{cm}^{-1}\right)$ was treated in a Simplicity 185 purification system (Millipore SAS, Molsheim, France).

\section{Preparation of calibration solutions and samples}

Standard solutions were prepared by dissolving $0.5 \mathrm{mg}$ of each standard in $10 \mathrm{~mL}$ of methanol. The lyophilized samples $(2 \quad \mathrm{~g})$ were after homogenization extracted with $20 \mathrm{~mL}$ of $80 \%$ methanol at laboratory temperature

by horizontal shaker (Unimax 2010; Heidolph Instrument GmbH, Germany) Extract was filtered through Munktell no. 390 paper (Munktell \& Filtrac, Germany) and stored in closed $20 \mathrm{~mL}$ vial tubes until the analysis. Prior the injection the standard solutions and sample extracts were filtered through syringe filter Q-Max (0.45 $\mu \mathrm{m}, 25$ mm; Frisenette ApS, Knebel, Denmark).

\section{HPLC analyses}

Phenolic acids and flavonoids were determined by using an Agilent 1260 Infinity high performance liquid chromatograph (Agilent Technologies, Waldbronn, Germany) and DAD detector (G1315C). All HPLC analyses were performed on Purosphere reverse phase $\mathrm{C} 18$ column $(4 \mathrm{~mm} \times 250 \mathrm{~mm} \times 5 \mu \mathrm{m})($ Merck, KGaA, Darmstadt, Germany). The detection wavelength was $320 \mathrm{~nm}$ for trans-caffeic acid, syringic acid, vitexin, ellagic acid, trans p-coumaric acid, trans-sinapic acid, ferulic acid, resveratrol, and $372 \mathrm{~nm}$ for daidzein and kaempferol.

\section{Spectrophotometric determination of total polyphenol content (TPC)}

TPC was determined by the method of Lachman et al. (2003) and expressed as milligrams of gallic acid equivalent per kilogram $\left(\mathrm{mg}\right.$ GAE. $\left.\mathrm{kg}^{-1}\right)$ dry weight. Gallic acid is usually used as a standard unit for phenolics content determination because of its wide spectrum of phenolic compounds. The total polyphenol content was estimated using the Folin-Ciocalteau assay and the absorbance was measured at $765 \mathrm{~nm}$ wavelength against blank (Spectrophotometer Shimadzu UV-1800 Shimadzu, Kyoto, Japan). The concentration of polyphenols was calculated from a standard curve plotted with known concentration of gallic acid.

\section{Statistical analysis}

The statistical differences between individual species were evaluated using a nonparametric statistical DUNN'S Multiple pairwise comparisons Kruskal-Wallis test at the level of significance $\mathrm{p}<0.05$. All calculations were performed by using MS Excel 2016 and XLSTAT (Addinsoft, 2014).

\section{RESULTS AND DISCUSSION}

Common bean (Phaseolus vulgaris L.) is an important source of macro- and microelements (Table 1 and 2), which are extremely important for correct process of metabolism. Their lack of inhibition of physiological processes in living organisms can cause various diseases (Bonafaccia et al., 2003).

Table 1 The content of macroelements in common bean seeds (mg.kg $\left.{ }^{-1} \mathrm{DM}\right)$

\begin{tabular}{|c|c|c|c|c|c|c|c|c|}
\hline Spiecies & Variety & $\mathbf{K}$ & $\mathrm{Na}$ & $\overline{\mathbf{C a}}$ & Mg & $\mathbf{P}$ & $\mathbf{F e}$ & Mn \\
\hline black beans & NEGRA & 10837 & 42.10 & 298.5 & 321.4 & 4744 & 77.60 & 15.40 \\
\hline red beans & RUBIN & 10985 & 48.20 & 144.6 & 255.7 & 3957 & 58.10 & 10.70 \\
\hline colour beans & INKA & 10892 & 157.4 & 406.3 & 304.8 & 3326 & 85.90 & 24.30 \\
\hline white beans & ZENIT & 12277 & 19.20 & 205.3 & 309.9 & 3262 & 51.00 & 18.10 \\
\hline Average & & 11248 & 66.73 & 263.7 & 279.9 & 3822 & 68.15 & 17.13 \\
\hline
\end{tabular}

Table 2 The content of microelements in common bean seeds ( $\left.\mathrm{mg} \mathrm{kg}^{1} \mathrm{DM}\right)$

\begin{tabular}{|c|c|c|c|c|c|c|}
\hline Species & Variety & Zn & $\mathrm{Cu}$ & Co & $\mathbf{N i}$ & $\mathrm{Cr}$ \\
\hline black beans & NEGRA & 15.3 & 6.40 & 0.10 & 5.40 & 2.70 \\
\hline red beans & RUBIN & 17.8 & 8.40 & 0.10 & 5.90 & 0.60 \\
\hline colour beans & INKA & 17.0 & 7.10 & 0.40 & 3.30 & 1.00 \\
\hline white beans & ZENIT & 16.2 & 3.80 & 1.10 & 1.70 & 0.70 \\
\hline Average & & 16.6 & 6.43 & 0.43 & 4.08 & 1.25 \\
\hline
\end{tabular}

Average

In Table 1 and 2 there are presented results of selected micro- and macroelements content in common bean seeds. Pedrosa et al. (2015) were also dealing same topic as we, determination of the mineral contents in common dry beans (Phaseolus vulgaris L.). They find out that the average content of $\mathrm{Fe}$ in common beans was $60.25 \mathrm{mg} . \mathrm{kg}^{-1}, \mathrm{Zn} 21.60$ mg. $\mathrm{kg}^{-1} \quad$ and according to this, our results are in correspondence with their results that they have obtained. Pedrosa et al. (2015) determinated the average value for Ca $1.60 \mathrm{mg} \cdot \mathrm{kg}^{-1}, \mathrm{Mg} 1.46 \mathrm{mg} \cdot \mathrm{kg}^{-1}, \mathrm{Na}$ $0.02 \mathrm{mg} \cdot \mathrm{kg}^{-1}$. Comparing to this findings, the results that we have obtained for this three elements ( $\mathrm{Ca}, \mathrm{Mg}$ and $\mathrm{Na}$ ) were significantly higher (Table 1 and 2). This can be caused by cultivation locality, variety, conditions of land and agricultural interventions (Bonafaccia et al., 2003).

In Table 3 are presented the results of the content of selected heavy metals in common beans seeds. The highest content of cadmium in the seeds was measured in the variety of the NEGRA-black beans $(0.50 \mathrm{mg} . \mathrm{kg}$ $\left.{ }^{1}\right)$. The lowest amount of cadmium was measured in the seeds of variety RUBIN-red beans $\left(0.08 \mathrm{mg} \cdot \mathrm{kg}^{-1}\right)$. The limit amount of cadmium, stated by The Food Code of the SR, is $0.1 \mathrm{mg} \cdot \mathrm{kg}^{-1}$.

\begin{tabular}{lllll} 
Table 3 The content of risk metals in common bean seeds $\left(\mathrm{mg}^{\left.-\mathrm{kg}^{-1} \mathrm{DM}\right)}\right.$ \\
\hline Species & Variety & Pb & Cd & Hg \\
\hline black beans & NEGRA & 1.40 & 0.50 & 0.003 \\
red beans & RUBIN & 1.60 & 0.08 & 0.002 \\
colour beans & INKA & 1.80 & 0.10 & 0.003 \\
white beans & ZENIT & 1.50 & 0.10 & 0.002 \\
\hline Limit (FC SR) & & $\mathbf{0 . 2}$ & $\mathbf{0 . 1}$ & $\mathbf{0 . 0 5}$ \\
\hline
\end{tabular}

FC SR- Food Code of the Slovak republic,

The $\mathrm{Pb}$ content in the seeds ranged from $1.40 \mathrm{mg} \cdot \mathrm{kg}^{-1}$ (NEGRA- black beans) to $1.80 \quad \mathrm{mg} \cdot \mathrm{kg}^{-1} \quad$ (INKA-colour beans) In all seeds of every variety, according to the legislation (FC SR: Pb $0.2 \mathrm{mg} \mathrm{kg}^{1}$ ), all the measured values were above this limit. Regarding to $\mathrm{Hg}$ content, all of the sample values were under the limit $(0.05$ mg.kg ${ }^{-1}$ ). Our results confirmed that all of our selected species (black, red, colour and white beans) have the ability to accumulate the heavy metals in seeds. Heavy metals are one of the biggest problems of environment in the world. They have a tendency to accumulate in living organisms. The huge amount of heavy metals is 
toxic or carcinogenic for human, animals, plants and microorganisms (Vardhan et al., 2019).

Table 4 The average contents of phenolic acids in common bean seeds (mg.kg $\left.{ }^{-1} \mathrm{DM}\right)$ - Multiple pairwise comparisons Kruskal-Wallis Tests,

\begin{tabular}{|c|c|c|c|c|c|c|c|}
\hline Spieces & Variety & tCA & SYA & ELA & tpCA & tSI & FA \\
\hline black beans & NEGRA & $0.0242^{\mathrm{b}}$ & $0.1080^{\mathrm{b}}$ & $0.1602^{b}$ & $0.0241^{\mathrm{b}}$ & $0.0388^{\mathrm{b}}$ & $0.1436^{\mathrm{b}}$ \\
\hline red beans & RUBIN & $0.0108^{b}$ & $0.1168^{b}$ & $0.2405^{\mathrm{b}}$ & $0.0107^{\mathrm{b}}$ & $0.0215^{\mathrm{b}}$ & $0.0657^{\mathrm{b}}$ \\
\hline colour beans & INKA & $0.0130^{\mathrm{b}}$ & $0.0991^{\mathrm{b}}$ & $0.1867^{\mathrm{b}}$ & $0.0368^{\mathrm{b}}$ & $0.0354^{\mathrm{b}}$ & $0.1059^{\mathrm{b}}$ \\
\hline white beans & ZENIT & $0.0472^{\mathrm{b}}$ & $0.1865^{b}$ & $0.2864^{\mathrm{b}}$ & $0.0251^{\mathrm{b}}$ & $0.0387^{\mathrm{b}}$ & $0.0751^{\mathrm{b}}$ \\
\hline
\end{tabular}

Different letters (a, b and $\mathrm{c}$ ) between the variables show statistically significant differences $(p<0,05)$.

- a $0,05>p>0,01$

-b $0,01>p>0,001$

- c $p<0,001$

- tCA- trans- caffeic acid, SYA- syringic acid, ELA- ellagic acid, tpCA-trans p-coumaric acid, tSI- trans- sinapic acid, FA- ferulic acid

Table 5 The average contents of flavonoids in common bean seeds (mg.kg-1 DM)

\begin{tabular}{lllll}
\hline Spieces & Variety & VIT & RES & KAE \\
\hline black beans & NEGRA & $0.0209^{\mathrm{b}}$ & $0.0046^{\mathrm{b}}$ & $0.0064^{\mathrm{b}}$ \\
red beans & RUBIN & $0.0234^{\mathrm{b}}$ & $0.0024^{\mathrm{b}}$ & $0.0046^{\mathrm{b}}$ \\
colour beans & INKA & $0.0259^{\mathrm{b}}$ & $0.0059^{\mathrm{b}}$ & $0.0054^{\mathrm{b}}$ \\
white beans & ZENIT & $0.0290^{\mathrm{b}}$ & $0.0106^{\mathrm{b}}$ & $0.0039^{\mathrm{b}}$ \\
\hline
\end{tabular}

- Multiple pairwise comparisons Kruskal-Wallis Tests,

Different letters $(\mathrm{a}, \mathrm{b}$ and $\mathrm{c})$ between the variables show statistically significant differences $(p<0,05)$.

- a $0,05>p>0,01$

- b $0,01>p>0,001$

- c $p<0,001$

- VIT- vitexin, RES- resveratrol, DAI- daidzein, KAE- kaempferol

In Table 4 and 5 are presented the results of polyphenols content in common bean seeds (mg. $\left.\mathrm{kg}^{-1} \mathrm{DM}\right)$. Trans- caffeic acid amount in seeds of selected varieties varied from $0.0108 \mathrm{mg} \cdot \mathrm{kg}^{-1}$ (RUBIN) to $0.0474 \mathrm{mg} \cdot \mathrm{kg}^{-1}$ (ZENIT). Giusti et al. (2017) find out that the values of trans- caffeic acid in seeds of selected varieties was under the detection limit, which is not corresponding with our results. The highest content of syringic acid was measured in the seeds of variety (ZENIT) 0.1865 mg. $\mathrm{kg}^{-1}$ and the lowest content was measured in the variety (INKA) $0.0991 \mathrm{mg} \cdot \mathrm{kg}^{-1}$. Based on this information, it is possible to create the following order of varieties: ZENIT $>$ RUBIN $>$ NEGRA $>$ INKA (Table 4). Giusti et al., (2017) published that the content of syringic acid was recorded in selected cultivars of beans in the interval from $1.8 \mathrm{mg} \cdot \mathrm{kg}^{-1}$ to $12.6 \mathrm{mg} \cdot \mathrm{kg}^{-1}$ DM. The content of ferulic acid was varied from $1.7 \mathrm{mg} . \mathrm{kg}^{-1}$ to $14.6 \mathrm{mg} \cdot \mathrm{kg}^{-1}$ DM.

The content of trans p-coumaric acid was under the limit of detection. The highest content of trans sinapic acid was measured in the seeds of variety (NEGRA) $0.0388 \mathrm{mg} . \mathrm{kg}^{-1}$ and the lowest content was in the variety (RUBIN) $0.0215 \mathrm{mg} \cdot \mathrm{kg}^{-1}$ (Table 4). Our results are lower, when compared to Lopez et al. (2013), who has published the content of trans sinapic acid 0.1 mg.kg-1 DM in dark beans (Phaseolus vulgaris L.). The highest content of kaempferol was measured in seeds of variety (INKA) $0.0082 \mathrm{mg} \cdot \mathrm{kg}^{-1}$ and the lowest content was in variety (NEGRA) $0.0046 \mathrm{mg} \cdot \mathrm{kg}^{-1}$ (Table 5). Lopez et al (2013) find out in their research that the content of kaempferol in dark bean seeds was under the detection limit, which is not corresponding with our results. Polyfenols content in common bean seeds was significantly lower, comparing to Lopez et al. (2013). It may be caused by cultivation locality, variety, conditions of land and agricultural interventions (Bonafaccia et al., 2003).

The statistical differences between individual species were evaluated using a nonparametric statistical DUNN'S Multiple pairwise comparisons Kruskal-Wallis test at the level of significance $p<0.05$. All of our statistical significant differences were at the significant level from 0.01 to 0.001 (letter b). There were found statistically significant differences in trans- caffeic acid between varieties RUBIN-red beans and ZENIT-white beans; syringic acid was between varietie INKA-colour beans and ZENIT-white beans; ellagic acid between varieties NEGRA-black beans and ZENIT- white beans; trans p-coumaric acid between varieties INKA-colour beans and RUBIN-red beans; ferulic acid between varieties RUBIN-red beans and NEGRA- black beans. In case of measured trans sinapic acid values, there were found statistically significant differences between varieties RUBIN-red beans/ZENIT-white beans/NEGRA-black beans (Table 4). In case of measured flavonoids resveratrol and daidzein between varieties RUBIN-red beans and ZENIT-white beans; kaempferol between varieties INKAcolour beans and ZENIT-white beans and vitexin between varieties NEGRAblack beans and ZENIT- white beans (Table 5).

Pitura et al. (2019) reported that in general, black bean seed coats had the greatest phenolic acid content followed from light to dark red bean that we can confirm with our findings. Padhi et al. (2017) published that the content of total polyphenols was recorded in selected cultivars of beans in the intervals from $1590 \mathrm{mg} \cdot \mathrm{kg}^{-1}$ to $4330 \mathrm{mg} \cdot \mathrm{kg}^{-1}$ DM. Comparing with our determined values of total polyphenols, their results were in similar interval. Our results are in correspondence with the results of Giusti et al., (2017) who indicated the content of total polyphenols in beans from $1120 \mathrm{mg} \cdot \mathrm{kg}^{-1}$ to $3880 \mathrm{mg} \cdot \mathrm{kg}^{-1} \mathrm{DM}$. There were found statistically significant differences in contents of total polyphenols between varieties ZENIT- white beans and NEGRA-black beans. Statistically significant highest TPC $(\mathrm{p}<0.05)$ was recorded in seeds in variety NEGRA-red beans
(2156.87 mg GAE.kg-1 DM). Statistically significant lowest content of total polyphenols

( $p<0.05)$ was recorded in seeds in variety ZENIT-white beans $(1362.70 \mathrm{mg}$ GAE.kg ${ }^{-1} \mathrm{DM}$ )

Table 6 The average contents of total polyphenols (mg GAE.kg-1 DM) in selected species and varieties common bean seeds.

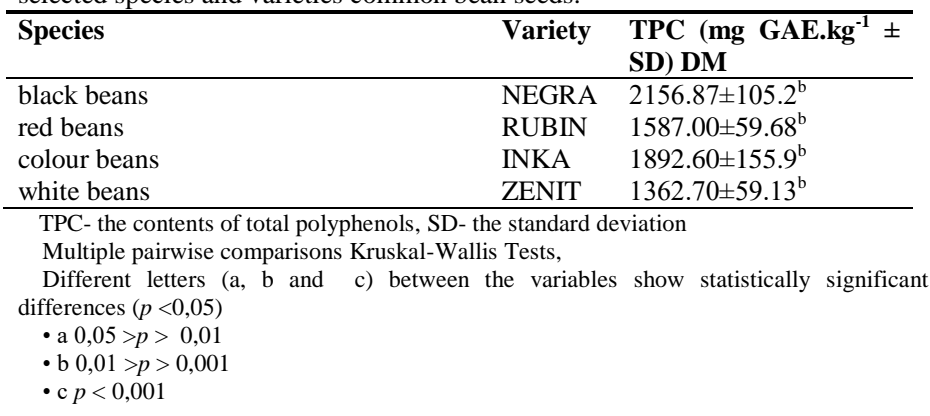

\section{CONCLUSION}

Common bean (Phaseolus vulgaris L.) is one of the most widely wide-spread legume specie in the world and that's why the aim of this work was to determinate the content of selected bioactive compounds. Common bean is very important nowadays. We have confirmed that the beans are characterized by an increased ability to cumulate some of the risk elements in the seeds. From the obtained results we found out that the limit values for $\mathrm{Pb}$ and $\mathrm{Cd}$ content, provided by the Slovak Food Code, exceeded in all seeds of the common bean varieties that were analysed. Seeds of the common beans are also characterized by a different content of bioactive substances (trans- caffeic acid $0.0108-0.0472 \mathrm{mg} . \mathrm{kg}^{-1}$ syringic acid $0.0991-0.1865 \mathrm{mg} . \mathrm{kg}^{-1}$, vitexin $0.0209-0.0290 \mathrm{mg} \cdot \mathrm{kg}^{-1}$, ellagic acid 0,1602-0,2864 mg.kg ${ }^{-1}$, trans p-coumaric acid $0.0107-0.0368 \mathrm{mg} \cdot \mathrm{kg}^{-1}$, trans sinapic acid $0.0215-0.0388 \mathrm{mg} \cdot \mathrm{kg}^{-1}$, ferulic acid $0.0657-0.1436 \mathrm{mg} \cdot \mathrm{kg}^{-1}$ resveratrol $0.0024-0.0106 \mathrm{mg} \cdot \mathrm{kg}^{-1}$, daidzein $0.0032-0.0089 \mathrm{mg} \cdot \mathrm{kg}^{-1}$ and kaempferol $0.0036-0.0082 \mathrm{mg} \cdot \mathrm{kg}^{-1}$ ). The highest macro element amount in common bean seeds was measured in K (12277 mg.kg-1 , ZENIT white beans) and the lowest amount was detected in Mn (10.70 mg. $\mathrm{kg}^{-1}$, RUBIN red beans). The highest microelements amount in common bean seeds was $\mathrm{Zn}\left(17.8 \mathrm{mg} \cdot \mathrm{kg}^{-1}\right.$, RUBIN red beans) and the lowest Co $\left(0.40 \mathrm{mg} \cdot \mathrm{kg}^{-1}\right.$, INKA colour beans).

Our chemical analyses revealed that the coloured seeds could be an excellent source of natural antioxidants, with demonstrating significantly higher content of total polyphenols. From the analysed varieties, NEGRA-black beans can be considered as the most important source of polyphenol substances with a demonstrable bioactive effect. Our results confirm that the type of crop, colour of the seeds also variety have an influence on the content of polyphenol compounds.

Acknowledgments: This study was supported by the grant VEGA no. 1/0139/17. 


\section{REFERENCES}

AGUILERA, Y., ESTRELLA, I., BENITEZ, V., ESTERBAN, R. M., MARTINCABREJAS, M. A. 2011. Bioactive phenolic compounds and functional properties of dehydrated bean flours. Food Research International, 44.3, 774 780. http://dx.doi.org/10.1016/j.foodres.2011.01.004

ALSHIKH, N., DE CAMARGO, A. C., SHAHIDI, F. 2015. Phenolics of selected lentil cultivars: Antioxidant activities and inhibition of low-density lipoprotein and DNA damage. Journal of functional foods, 18, 1022-1038. https://dx.doi.org/10.1016/i.jff.2015.05.018

ARRIBAS, C., EliANA P., LILLIAN, B. M., JOSÉ, A. R., CALHELHA, E.G.M., FERREIRA, C.F.R. 2019. Healthy novel gluten-free formulations based on beans, carob fruit and rice: Extrusion effect on organic acids, tocopherols, phenolic compounds and bioactivity. Food chemistry, 292, 304-313 https://dx.doi.org/10.1016/j.foodchem.2019.04.074

BONAFACCIA, G., MAROCCHINI, M., KREFT, I. 2003. Composition and technological properties of the flour and bran common and tatary buckwheat. Food Chemistry, 80, 9-15. https://doi.org/10.1016/S0308 8146(02)00228-5

GIUSTI, F., CAPRIOLI, G., RICCIUTELLI, M., VITTORI, S., \& SAGRATINI, G. (2017). Determination of fourteen polyphenols in pulses by high performance liquid chromatography-diode array detection (HPLC-DAD) and correlation study with antioxidant activity and colour. Food chemistry, 221, 689-697. https://doi.org/10.1016/j.foodchem.2016.11.118

HERRERA, M.D., ACOSTA-GALLEGOS, J.A., REYNOSO-CAMACHO, R. PÉREZ-RAMÍREZ, I.F. 2019. Common bean seeds from plants subjected to severe drought, restricted-and full-irrigation regimes show differential phytochemical fingerprint. Food chemistry, 294, 368-377. https://dx.doi.org/10.1016/j.foodchem.2019.05.076

KUETE, V. 2014. Physical, hematological, and histopathological signs of toxicity induced by African medicinal plants. In: Toxicological Survey of African Medicinal Plants. Elsevier,22, 635-657. https://doi.org/10.1016/B978-0-12800018-2.00022-4

LACHMAN, J., PRONEK, D., HEJTMANKOVA, A., DUDJAK, J., PIVEC, V., FAITOVÁ, K. 2003. Total polyphenol and main flavonoid antioxidants in different onion (Allium cepa L.) varieties. Horticultural science, 30(4), 142-147. https://dx.doi.org/10.17221/3876-HORTSCI.

LI, L.-F.; OLSEN, K. M. 2016. To have and to hold: selection for seed and fruit retention during crop domestication. In: Current topics in developmental biology. Academic Press, 63-109. https://dx.doi.org/10.1016/bs.ctdb.2016.02.002

LOPEZ, A., EL-NAGGAR, T., DUEÑAS, M., ORTEGA, T., ESTRELLA, I, HERNÁNDEZ, T., .. \& CARRETERO, M. E. (2013). Effect of cooking and germination on phenolic composition and biological properties of dark beans (Phaseolus vulgaris L.). Food Chemistry, 138(1), 547-555. https://doi.org/10.1016/j.foodchem.2012.10.107

MIRALI, M., AMBROSE, S.J., WOOD, S.A., VANDENBERG,A., PURVES, R.W. 2014. Development of a fast extraction method and optimization of liquid chromatography-mass spectrometry for the analysis of phenolic compounds in lentil seed coats. Journal $\begin{array}{lllll}\text { of } & \text { Chromatography } & B, & 969, & 149-161\end{array}$ https://doi.org/10.1016/j.jchromb.2014.08.007

NEMLI, S., KIANOOSH, T., TANYOLAC, M. B. 2015. Genetic diversity and population structure of common bean (Phaseolus vulgaris L.) accessions through retrotransposon-based interprimer binding sites (iPBSs) markers. Turkish Journal of Agriculture and Forestry, 39.6, 940-948 https://dx.doi.org/10.1016/j.jchromb.2014.08.007

PADHI, E. M., LIU, R., HERNANDEZ, M., TSAO, R., \& RAMDATH, D. D. 2017. Total polyphenol content, carotenoid, tocophero and fatty acid composition of commonly consumed Canadian pulses and their contribution to antioxidant activity. Journal of Functional Foods, 38, 602-611.

https://dx.doi.org/10.1016/j.jff.2016.11.006

PEDROSA, M. M., CUADRADO, C., BURBANO, C., MUZQUIZA, M., CABELLOS, B., OLMEDILLA-ALONSO, B., ASENSIO-VEGAS, C. 2015 Effects of industrial canning on the proximate composition, bioactive compounds contents and nutritional profile of two Spanish common dry beans (Phaseolus $\begin{array}{lllll}\text { vulgaris } & \text { L.). } & \text { Food } & \text { Chemistry, } & \text { 166, }\end{array}$ https://dx.doi.org/10.1016/j.foodchem.2014.05.158Get

PITURA, K.,ARNTFIELD, S. D. 2019. Characteristics of flavonol glycosides in bean (Phaseolus vulgaris L.) seed coats. Food chemistry, 272, 26-32. https://dx.doi.org/10.1016/j.foodchem.2018.07.220

YADAV, A., KUMARI, R., YADAV, A., PRABHA, S. 2016. Antioxidant and its functions in human body - A Review. Research in Environment and Life Sciences, 9(11), 1328-1331. ISSN: 0974-4908. http://vincerehealth.com/wp-content/uploads/2018/08/Antioxidant-function-

review-2016.pdf

VARDHAN, K. H., KUMAR, P. S., PANDA, R. C. 2019. A review on heavy metal pollution, toxicity and remedial measures: Current trends and future perspectives. Journal of Molecular Liquids,290, 111197. https://doi.org/10.1016/j.molliq.2019.111197 